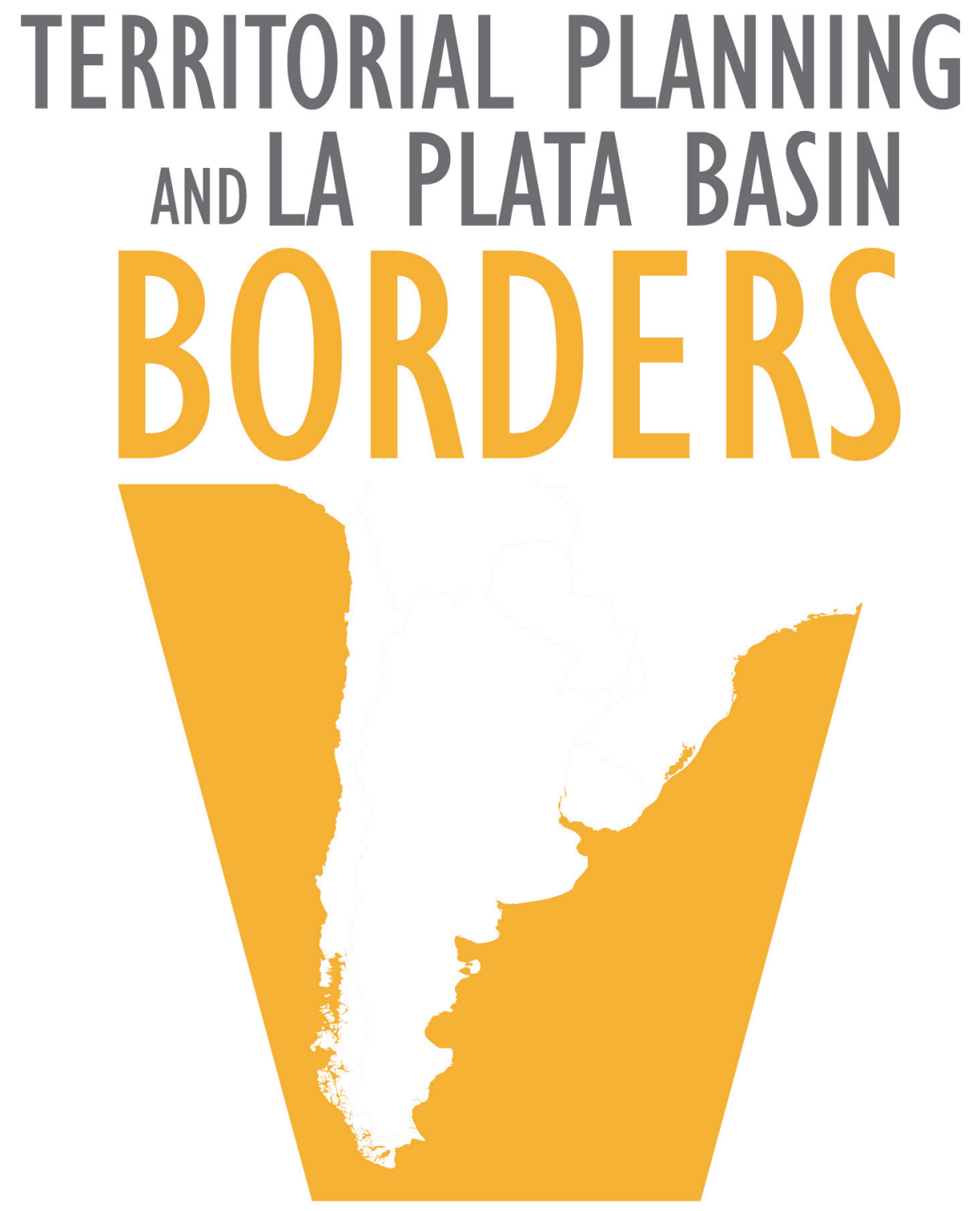

Antonio Paulo Cargnin

Aldomar Arnaldo Rückert Bruno de Oliveira Lemos

(Eds.) 


\section{Editors}

Antonio Paulo Cargnin

Aldomar Arnaldo Rückert

Bruno de Oliveira Lemos

\section{Editorial Board}

Carla Giane Soares da Cunha

Fernando Dreissig de Moraes

Irma Carina Macolmes

\section{Language Review}

Marlise Margô Henrich

\section{Layout}

Diego MeneghettI

Ronaldo Machado

\section{Cover Design}

Laurie Fofonka Cunha

\section{Institutional support}

Programa de Pós-Graduação em Geografia (POSGEA)

Instituto de Geociências (IGEO)

Universidade Federal do Rio Grande do Sul (UFRGS), Brazil

Secretaria de Planejamento, Governança e Gestão (SPGG)

Governo do Estado do Rio Grande do Sul, Brazil

\section{Dados Internacionais de Publicação}

Bibliotecária Regina de Carvalho Pereira CRB8/91772

\section{Letra1}

www.editoraletra1.com.br letra1@editoraletra1.com (+5551) 33729222 Rua Lopo Gonçalves, 554 Cidade Baixa 90050-350 Porto Alegre, RS, Brazil CNPJ I 2.062.268/000I-37
T327 Territorial planning and La Plata Basin borders / Antonio Paulo Cargnin, Aldomar Arnaldo Rückert, Bruno de Oliveira Lemos (Eds.) . - Porto Alegre : Editora Letra1, 2018. 232p.

ISBN 978-85-63800-35-0 DOI 10.21826/9788563800350

1. Brasil - Fronteiras.2. La Plata - Fronteira. 3. Território. I. Cargnin, Antonio Paulo. II. Rückert, Aldomar Arnaldo. III Lemos, Bruno de Oliveira. III. Título.

CDD 320.12 


\title{
VII IIRSA-COSIPLAN AND THE GARABI-PANAMBI HYDROELECTRIC COMPLEX IN THE HISTORICAL MISSIONARY TERRITORY
}

\author{
Ludmila Losada da Fonseca \& Aldomar Arnaldo Rückert
}

\section{ABSTRACT}

The Initiative for the Integration of the Regional Infrastructure of South America (IIRSA), led by the Brazilian government, began in the 2000s to meet the demands and solve the lack of investment in infrastructure. In 2010, IIRSA was incorporated into the South American Infrastructure and Planning Council (COSIPLAN) of the Union of South American Nations (USAN). This initiative included in its portfolio old projects that have been left aside over time, one of which was the construction of two dams on the Uruguay River, on the border between Brazil and Argentina, whose project is currently called the Garabi-Panambi Hydroelectric Complex. The construction of dams on the Uruguay River dates back to the 1960s, when the urban centers increased their demand for energy. With this still existing demand, the projects continue to be agenda and emerge as possible promoters of regional integration. The implementation of Garabi and Panambi, which have not begun yet, have an impact on the host municipalities - already identified by the Movement of Dam Affected People (MAB) and the mayors of the host municipalities. This insertion of the IIRSACOSIPLAN through the project of the Hydroelectric Complex in the historical missionary territory reveals the imposition of a project due to the absence of dialogue between municipalities and the State, as well as the lack of dialogue with the civil society.

KEYWORDS Garabi-Panambi hydroelectric complex, regional integration, Integration of the Regional Infrastructure of South America. 
The South American subcontinent followed the post-Cold War world trend of forming regional trade blocks. This movement was motivated by a decreasing economic influence of great powers (Europe and the United States), compared to what happened during the Cold War (1945-1991), when they sought to hinder the socialist influence in the American continent (Hurrell, 1993). Thus, this new stage allows integration and cooperation through regional trade blocks ${ }^{1}$. Therefore, this would be an opportunity for underdeveloped countries to play a major role internationally. According to Santos (2011), globalization is the culmination of the capital internationalization process, due to the development of techniques, more precisely in the field of communication, and political actions that permit the emergence of this global market.

These initiatives interrupted a logic that for centuries pointed abroad, which prioritized bilateral relations or agreements with the developed countries that operated mostly with imperialist attitudes. As a result of this new scenario, the Initiative for the Integration of the Regional Infrastructure of South America (IIRSA) and the Union of South American Nations (USAN) are born, and the former is incorporated into the latter in 2010. In 2000, IIRSA was officially created in Brasília, and it sought to physically integrate the South American countries by the modernization of infrastructures, to promote economic and social development.

The South American Infrastructure and PlanningCouncil (COSIPLAN), which is a space for discussion on policies and strategies that aim to implement programs and projects for the integration of infrastructure, emerged from the importance of IIRSA to the integration proposed by USAN (IIRSA, 2012). Thus, USAN develops projects associated with COSIPLAN and, consequently, with IIRSA, which is its technical forum. This integration project seeks to integrate South America through this set of projects, namely on transportation (construction of different waterways, railways or motorways), communication and energy (power generation and interconnection). In order to achieve this, there are nine spatially distributed Integration and Development Axes (EIDs), which include the projects. The EIDs are divided into: Amazon, Andean, Capricorn, Guiana Shield, Paraguay-Paraná

\footnotetext{
1 According to Roseira (2011), regional blocks articulate different political and economic scales, creating a force contrary to globalization, seeking cooperation among the Member States.
} 
Waterway, Central Interoceanic, MERCOSUR-Chile, Peru-Brazil-Bolivia, and Southern Axis.

With this structure, IIRSA-COSIPLAN adds geopolitical projects in each space because, when an initiative that changes the use of a territory is implemented, a political and strategic use of it is also made, thus marking a power projection.

The Garabi-Panambi Hydroelectric Complex was chosen as the object of this study in order to understand how an IIRSA-COSIPLAN project is implemented and what its repercussions are. This project will be located on the Uruguay River, on the border between Brazil and Argentina, although it has not been started yet. This field research identified and interviewed the local territorial actors (mayors and social movements) in the municipalities that will host the hydroelectric plants: Garruchos and Alecrim, in Rio Grande do Sul State (RS), Brazil. They are both located in a region that, in this article, will be called Historic Missionary Territory, a space where a history marked by the presence of the Guarani people, European settlers, and Jesuit priests was constructed. Although not officially considered as a territory, this space still shows traits of a time when the limits of the States were absent.

\section{IIRSA-COSIPLAN}

Projects that aimed to integrate the infrastructure in South America were designed and theorized long before their implementation, and the IIRSACOSIPLAN initiative was no different. Hirt (2013) points out that the IIRSA theoretical framework is based on two studies. Infrastructure for Sustainable Development and Integration of South America, a study Eliezer Batista conducted in 1996 for $\mathrm{CAF}^{2}$, was based on the "geo-economic conception and technical analysis of the initiative" (Padula, 2014, p. 312). Un nuevo impulso a la integración de la infraestructura regional en América del Sur, a study carried out by IDB $^{3}$ was also used to formulate the IIRSA. It identified the problems that hinder trade growth in South America, structured the subcontinent in axes, aiming at a broader interchange with international economies (VITTE, 2006).

In the 2000s, after these studies were conducted and the discussion had begun, during the $40^{\text {th }}$ anniversary of IDB (Vitte, 2006), the presidents of South American

\footnotetext{
2 Andean Development Corporation - Development Bank of Latin America

3 Inter-American Development Bank
} 
countries met in Brasília to promote solutions to the logistical problems the subcontinent faced. According to Padula (2014), these deficiencies may be both due to geographical barriers and the absence of investments in this sector. The importance of solving these problems lays in the dependence of South American economies on the export of commodities, generating a need for large and dense infrastructure, especially for transportation, mostly the intermodal freight transport. Thus, as Vitte (2006) points out, IIRSA aims at a "new wave of modernization of productive infrastructures" (Vitte, 2006, p. 34), in order to strengthen the local economies within the international market.

The criticism to IIRSA-COSIPLAN is based on the fact that EIDs clearly ease the flow of commodities destined for export to Europe (via the Atlantic Ocean) and Asia (via the Pacific Ocean). If the only impetus were to integrate the subcontinent, the axes could connect the countries from north to south. On the other hand, it is noteworthy that, whenever a highway or other transportation modal is built, its use is not restricted to a commercial area; it can also be used for the transit of people, thus, at the same time, it is an advantage for a certain population. When the object of this study is considered, namely a hydroelectric power plant, this double advantage is also present: it is built aiming at increasing electricity generation to support the domestic - and South American - development, but it also creates jobs and changes the local reality. It is worth noting that the latter example implies some local damages, to be presented below.

The objective of the IIRSA-COSIPLAN is clear when the projects that comprise its portfolio are analyzed: they are mainly focused on the transportation sector (89\%). From the projects that are being implemented, 90\% of them are transportationoriented, and, from the concluded projects, approximately $40 \%$ were in the road transportation field (UNASUL, 2017). No other sector contributes more objectively to the flow of commodities than that aimed at transportation, majorly for the modernization and construction of new highways, thus strengthening the construction of bioceanic corridors and connecting productive areas to large centers and port cities, which function as flow points.

Some of the IIRSA-COSIPLAN projects are located in the historical missionary territory, which includes three integration axes: Mercosur-Chile Axis, ParaguayParaná Waterway Axis, and Capricorn Axis. Since it is a border region, it is strategic for the full integration of South America. 


\section{THE HISTORICAL MISSIONARY TERRITORY}

This study covers a perimeter that today comprises the border region among Argentina, Paraguay, Uruguay, and Brazil, and is defined here as a historical missionary territory. This territory is now left in the past, surpassed by current political divisions, but its ruins are vestiges of that historical moment, which was then a territory that housed about 100,000 Guarani people catechized by Jesuit priests. Those countries share a common missionary past in that - currently border region. In this same region, Brazil, Paraguay, and Argentina have developed important projects in the hydroelectric power generation sector, namely Itá, Itaipu, and Yacyretá; and soon Garabi-Panambi, whose construction is planned for the coming years. Currently, a new dispute is in progress in the historical missionary territory, which is no longer characterized by a polarization between the colonizers and the colonized (traditional communities), but a multipolarization of different interests and intentions of the territorial actors who play a part there.

When dealing with the history that pervades the historical missionary territory, and what it has left as a present heritage, it is essential to consider the cultural aspects of the indigenous society before and after the Jesuit Reductions. What remains of the time of the historical missionary territory is evident in the still existing ruins (Levinton; Snihur, 2011). This roughness ${ }^{4}$ marks a time in space when the territory was destined for the use of the natives and later for European exploitation; at that time, that region did not comprise the Nation States.

Marked by power struggle and the notion of limits, this territory requires deep understanding, even if there is no agreement as to its conceptualization. Etymologically, Lobato Corrêa reminds us that the word territory has its origin in the Latin terms terra and torium, meaning "land that belongs to someone." However, Corrêa states that belonging "is not necessarily related to land ownership, but to its appropriation" (Corrêa, 1998, p. 251). As historically demonstrated, the Guarani people effectively appropriated that land, made it their livelihood, and left their marks, which are present to date.

\footnotetext{
4 According to Santos (2009), roughness is what remains of the past as a form, a constructed space, a landscape, remains of the process of suppression, accumulation, superposition, with which things are replaced and accumulated everywhere. Roughness appears as isolated forms or arrangements. Although without an immediate translation, roughness brings us the remnants from divisions of labor that are already gone.
} 
This space is approached as a territory instead of being conceptualized as a region because, since the Iberian settlers arrived in the $16^{\text {th }}$ century, the former is characterized by power struggle. Santos and Silveira (2001) support this reflection when they state that a territory, seen as unity and diversity, is a central issue of human history and of each country, constituting the background for the study of its several stages and its present time.

Other authors also use the term territory to study this subject. For instance, Schallenberger (2007) states that the "Guarani territory" was limited from the control of space, and Santos and Rückert (2014) use the concept of "Missionary Transfrontier Territory," emphasizing that the territory is located in a border among Brazil, Paraguay, Argentina, and Uruguay. Another fact that supports the defense of the missionary territory is found in a study by Nogueira (2007), which uses the spatial delimitation of the missionary expansion introduced by Abou in 1996, as shown in Figure 1. The limits established by the area of activity of the Jesuit Missions, where the Thirty Peoples were located, support our understanding of it as a territory.

Although currently there is no conception of the existence of a missionary territory, since it has been surpassed by the existence of colonies and later by the Nation States (Brazil, Argentina, Uruguay, and Paraguay), this historical term reveals past issues and disputes that are alive and present to date. When the territory is considered as endowed with "[...] a plural, diverse, contradictory reality" (Rosière, 2007 , p. 24), it is understood that the territory now fragmented into Nation States can have this past territorialities, which can confront each other at a given moment.

The regions where the mission ruins are located are characterized by poverty, with limited resources, particularly due to their economic matrix (Nogueira, 2007). This fact makes the preservation of these historical and cultural antecedents even more important and relevant, as they are a fundamental source of income for their towns and population. It is worth noting that tourism, through exploration of the ruins and this missionary history, is an important tool for local development, which needs to be further encouraged by national governments, since South Americans are willing to know their own history and that of their neighbors, a fact supported by data from 2014 concerning the circulation of Brazilian, Paraguayan, and Argentinian citizens in these countries ${ }^{5}$. In this sense, with the construction of the

5 In 2014, 293,000 Paraguayans and 1.7 million Argentinians visited Brazil. 180,000 Brazilians and 300,000 Argentinians traveled to Paraguay. One million Brazilians and 600,000 Paraguayans visited Argentina (INDEC, 2014, Senatur, 2014, BRASIL, 2014). 


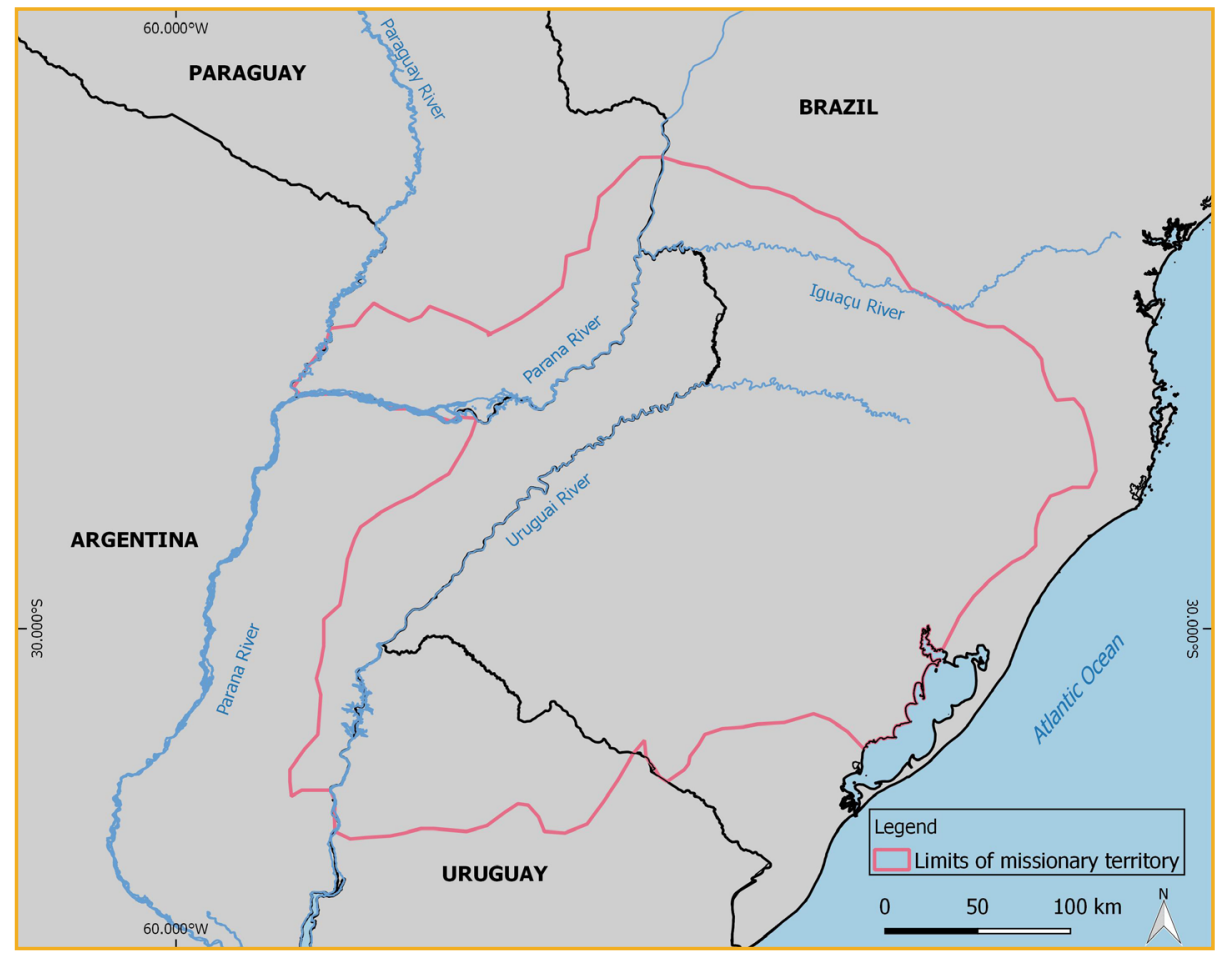

Figure I. Limits of the Missionary Territory.

Source: Abou (1996) apud Nogueira (2007).

hydroelectric complex, some kind of development could be expected for the region, as well as some tourism connecting the hydroelectric plants with the Jesuit ruins.

\section{ENERGY INTEGRATION: THE HYDROELECTRIC POWER PLANTS IN THE HISTORIC MISSIONARY TERRITORY}

The waters of the rivers that make up La Plata Basin were of great importance for the settlement of the Guarani people and the Jesuit Missions, as well as for the delimitation of the territory. At the time, the water resource was considered a good because it was necessary for the maintenance of life (for drinking, fishing, bathing). Currently, one of the main uses of a river is generating electricity through a dam.

Energy generation is the starting point and the essential condition for economic development, besides having paramount importance in the daily lives of populations. 
Energy integration may support the region's self-sufficiency in energy production, providing it with security and independence in this sector, enabling the countries to have greater power in the international system. In addition, this integration may solve the problems of energy deficit in countries such as Argentina, Chile, and Uruguay (Padula, 2014). The energy interdependence of the South American countries shows their state of maturity and pacifism.

Hydroelectric energy is a priority way to supply the region studied due to the water volume and its availability, and also because of the rivers' favorable physical characteristics. The investment in the construction of hydroelectric plants in Brazil arises from the greater participation of the country in energy production during the 1950s, under the discourse of promoting industrialization, since until then production was controlled by foreign companies. In this context, a bilateral agreement was signed between Brazil and Paraguay in the 1960s for the construction of Itaipu, the first major hydroelectric project in the historical missionary territory, whose investment totaled 27 billion American dollars. Another major hydroelectric power plant was Yacyretá, an Argentine and Paraguayan venture on the Paraná River, which began to be built in 1983, but was inaugurated only in 1998, costing 15 billion American dollars to both countries (EBY, 2009). This hydroelectric plant is strategic for Argentina because it supported the country's urbanization and, consequently, its increased energy consumption.

Despite the negative repercussions concerning the construction of hydroelectric plants (removal of local populations, deforestation, changes in river dynamics, environmental and social impacts), it is necessary to consider the vital participation of hydroelectric plants installed in the historical missionary territory for energy generation in the countries involved. In 2014, Itaipu supplied $75 \%$ of the energy consumed in Paraguay and 17\% of the energy used in Brazil (Itaipu Binacional, 2014). Likewise, Yacyretá currently accounts for $22 \%$ of the electricity consumed in Argentina.

The Uruguay River, where the Garabi-Panambi power plant will be installed, is located on the border among Brazil, Argentina and Uruguay. Historically, the boundary of these countries is characterized by the presence of hydroelectric dams due to its longitudinal waterway profile with waterfalls, which are useful for hydroelectric use. The river is $2,200 \mathrm{~km}$ long, its spring is located on the border between the states of Santa Catarina and Rio Grande do Sul, and its mouth is 
located on the border with Uruguay. The use of this important river has its historical records since the late 1960s, as suggests the first inventory study. It was only in 1976 that the border region was intended to build hydroelectric plants, making it necessary to update the studies.

This joint action between Brazil and Argentina, concerning the use of the Uruguay River, could only be carried out because of the existence of the "Agreement between the Government of the Argentine Republic and the Government of the Federative Republic of Brazil for the Use of Shared Water Resources in the Boundary Zones of the Uruguay River and its Tributary Pepiri-Guaçu", signed by both countries in the 1980s for the use of the river. It is assumed that the joint actions will take place between the state-owned companies designated as responsible for implementing the hydropower plants, namely ELETROBRAS and EBISA (ELETROBRAS, 2010).

\section{THE GARABI-PANAMBI HYDROELETRIC COMPLEX}

In 2008, the binational hydroelectric projects were resumed in the historical missionary territory to take advantage of the regional hydro potential, thus encouraging energy integration. As an example of this new moment, the initiative of the presidents of Brazil and Argentina at that time, Luiz Inácio Lula da Silva and Cristina Férnandez Kirchner, authorized the state-owned companies, respectively, Centrais Elétricas Brasileiras S.A. (ELETROBRAS) and Emprendimientos Energéticos Binacionales (EBISA), responsible for the generation, transmission and distribution of energy, to start feasibility studies for the construction of two new hydroelectric plants on the Uruguay River, on the border between both countries. This initiative will be achieved through the construction of the Garabi and Panambi plants, forming the Garabi-Panambi Hydropower Complex, which is part of the IIRSA-COSIPLAN project portfolio in the MERCOSUR-Chile Integration and Development Axis.

By means of inventory studies carried out by ELETROBRAS and EBISA, the Garabi dam will be built in the municipalities of Garruchos, Brazil, and Garruchos, Argentina, and the Panambi dam will be built in Alecrim and Panambí, respectively in Brazil and Argentina. Even considering the relevance of power generation for the subcontinent, and knowing that, currently, smaller dams are built to mitigate negative impacts, several territorial consequences from the construction 
of a hydroelectric plant are still predicted. The most mentioned ones are removal of people, reduction of biodiversity, the end of topophilic relationships, and uncertainties about the future.

In 2011, it was announced the resumption of binational hydroelectric projects in the historical missionary territory. At that time, the presidents of Brazil and Argentina, Dilma Rousseff and Cristina Kirchner, authorized the state-owned companies to start new feasibility studies. Thus, the Garabi and Panambi plants were designed for a total capacity of 2,200 MW, an estimated cost of 5.2 billion American dollars, having, if built, major direct and indirect impacts in the several municipalities of the region, as shown in Figure 2.

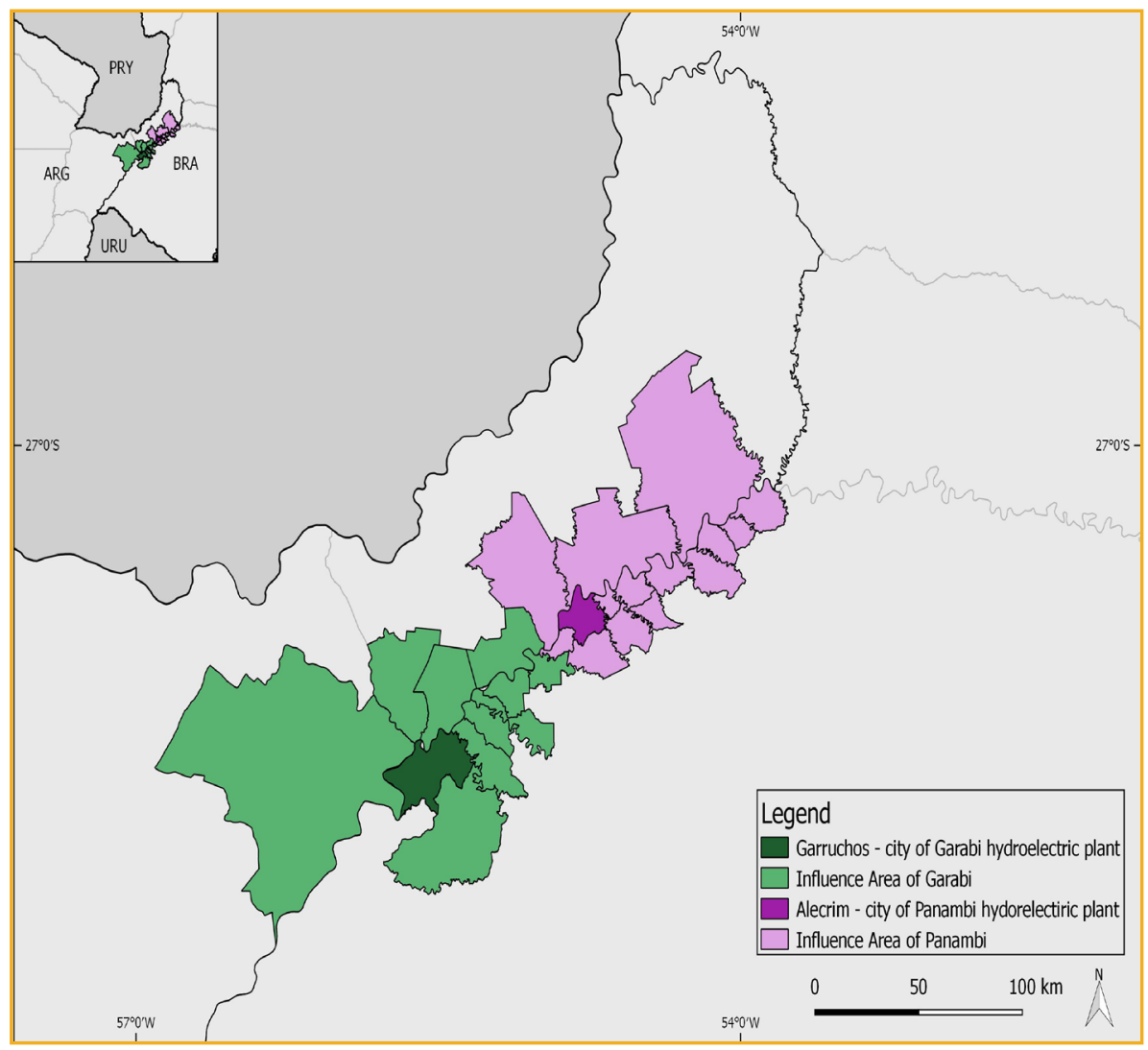

Figure 2. Area of Direct Influence of Hydroelectrics 
Now, to enhance the knowledge about the local reality, it is necessary to analyze the socio-economic profile of the Brazilian municipalities that will host the Garabi-Panambi Complex, Alecrim and Garruchos, located in the northwest of Rio Grande do Sul State, using data from the Brazilian Institute of Geography and Statistics (IBGE, 2016). It is noteworthy that, historically, the border region, which was characterized by poverty indices and scarce investment, is neglected by local governments.

The municipality of Alecrim, located in the northwest of Rio Grande do Sul, had an estimated population of 6,800 inhabitants in 2016, a figure that decreases continuously (IBGE, 2016). Due to urban hierarchy, the town assumes the role of a regional center, with only local influence. In addition, Alecrim disassociates itself from what occurs in the population standard, since most of its citizens reside in the rural area. It has a strong presence of agricultural business, especially soybean farming (IBGE, 2016). The municipal GDP per capita is a little more than 12 thousand Reais; the income of the majority of citizens is, however, between half and two minimum wages ${ }^{6}$ (IBGE, 2016). The local Human Development Index (HDI) is 0.672 - below the Brazilian HDI, which is considered medium by the UN.

Garruchos is a municipality that has shown a slightly decreasing population, from 3,234 in 2010 to 3,219 in 2015 (IBGE, 2016). The reality of the municipality is marked by the difficult access, since unpaved RS-176 is away from BR-285, an important road in the region. This makes the town growth unfeasible. Garabi I and Garabi II converters, which integrate an existing system between Brazil and Argentina to transmit electricity between both countries, are currently located in Garruchos.

Since the Garabi-Panambi Hydroelectric Complex is located on the border between Brazil and Argentina, it is also necessary to recognize the reality of the Argentinean localities. Corrientes and Misiones, characterized by the lowest HDI in the country, are the provinces that will be affected by the construction of the Hydroelectric Complex (UNASUR, 2014). Both provinces, respectively, have $14.2 \%$ and $12.7 \%$ of their territory protected by environmental laws, a number considered relevant when compared to data from Rio Grande do Sul, which is $3.2 \%$ (UNASUR, 2014).

6 In 2017, the Brazilian minimum wage is 937 Reais, which is around 295 American dollars. 
Although the Hydroelectric Complex is an old project, the IIRSA-COSIPLAN portfolio of projects assimilated both plants without modifications but separately. Thus, Garabi and Panambi have independent projects. Both are currently in the pre-execution phase. The IIRSA-COSIPLAN description for the Garabi project includes eight turbines, which spin generators to have a maximum installed power capacity of 1,152 MW. Also according to the inventory prepared in 2010, the reservoir flooded area would be $642 \mathrm{~km}^{2}$, with maximum level of 89 meters. Projects related to the installation of the hydroelectric plant are not presented in that report (IIRSA-COSIPLAN, 2017a). Besides, the Panambi hydroelectric power plant project includes seven turbines, with an installed power capacity of 1,048MW and a maximum level of 130 meters (IIRSA-COSIPLAN, 2017b). Along with Panambi plant, the project will cost about five billion dollars of public money, yet there is still no formal action in the pursuit of investments.

The implementation of the hydroelectric plants is slow. Although new studies started in 2010, only in 2014 IBAMA $^{7}$ issued the term of reference, a document necessary to start environmental studies, pointing out the items that these studies should comprise. From that moment, studies on the biotic environment of the region and engineering plans were carried out. At the end of that year, informative meetings were held with the local populations affected in Brazil. Currently, according to the project follow-up report, cultural and archaeological diagnosis studies have been carried out also on the Brazilian side ${ }^{8}$.

\section{A TERRITORY IN DISPUTE}

Considering the set of intentions of IIRSA-COSIPLAN and the implementation of new elements in the territory, it is necessary to reiterate the war of interests for territory use.In this sense, Hirt (2013) states that the central conflict of IIRSA lies in the socio-political and territorial issue. Territory is a space defined and delimited by and from power relationships. Therefore, existing conflicts over territory are common and constitute it.It is on the local scale that the conflicts and disputes over the territory use will occur, but with IIRSA-COSIPLAN this conflict is masked,

\footnotetext{
7 Brazilian Institute of Environment and Renewable Natural Resources.

8 In Brazil, the implementation of the hydroelectric plant is discussed judicially, generating, as an effect, the suspension of the environmental impact studies of the Panambi hydroelectric plant due to the repercussion it would bring to an environmental preservation area.
} 
because those who work locally for the countries in the name of integration are the construction companies responsible for the execution of the works.

In order to gain a better insight into the implementation of the project and its expected impacts, we considered the opinions of those who are on the "edge" of this process. Therefore, the territorial actors present at more local scales were considered, since, as Dietz (2008, p.112) states, "it is at a local scale [...] that the relations produced at the other geographical scales take place", as pointed out before.Tothisend, we interviewed municipal government representatives of the 2013-2016 legislature from the two host cities in the project and a representative of the Movement of Dam Affected People (MAB), social movement that legitimately represents those who will be affected by the dams.

During the research, the following items were identified as the main impacts: the environmental issue, the topophilic attachments and the process of deterritorialization', since it is understood that the implementation of GarabiPanambi unavoidably implies removal of people, action that was present in the implementation analysis of other hydroelectric projects.It is still noticed that, when the territorial actors of national and international scales decide on a project of local interference, due to an imposition, to an economic dynamics that is spatially materialized, it hardly ever fails to be executed, even if it was rejected by the population.

Given this idea, the next step is understanding the local territorial actors identified (MAB and mayors of the host cities) and their views on the implementation and the impacts of the project. $\mathrm{MAB}$ is considered a national and local territorial actor, who joins the territorial dispute when fighting for another model of development in which hydroelectric dams are not the only alternative for energy production. The Movement of Dam Affected People was already present in the cities affected by this Hydroelectric Complex when the first proposal was made in the decade of 1970 by demand of the affected people, and it was organized regionally.

For the MAB representative, the number of people affected will be higher than what is expected by those in charge of the studies made. The fact that dam constructions affect a large number of people is what supports one of the main

9 Removal triggers a process of deterritorialization characterized, according to Haesbaert (2003), by its social nature, which is linked to the increasing dynamics of socio-spatial exclusion. Deterritorialization is linked to the uprooting and weakening of territorial identities. 
demands of the movement: the existence of a national policy for dam affected people (PNAB).It would establish a protocol of procedures for the implementation of a dam. The representative of the movement also highlights that the hydroelectric plants are extremely profitable not only for the municipalities that will host them (Garruchos and Alecrim), because of the royalties received, but also for the companies that will control them, since the cost of the energy produced is much lower in comparison to its sales value, making energy production a profitable business.

The movement understands the fact that the Garabi-Panambi Hydroelectric Complex is associated with an integration project, since they see it as an initiative of IIRSA. However, within IIRSA there is no recognized space for demands or criticisms about the project: these claims are made to the state and federal government.

As representatives of the public administration at a more local level, the mayors of the municipalities (2013-2016 term of office) of Garruchos and Alecrim, site of the future Garambi and Panambi dams, were interviewed.

The mayor of the municipality of Alecrim points out the difficulty of projecting any type of territorial impact there can be in the town, as he considers that this will depend on several factors, such as: the work sites - still without definition - and the workers' settlement, the logistics required for construction, the demands for schools and for public health and the way the project will affect the public safety in the municipality. Thus, he considers that there is no way that such an undertaking will have no impacts in the municipality; however, he points out that the population of Alecrim can not have their access to public equipment hindered without any compensatory measures prior to this undertaking for the damage mentioned.

It was verified that the municipality of Alecrim has no participation in the implementation of the Panambi hydroelectric plant, had no compensation or obligation, nor was it consulted about hosting the hydroelectric dam, since this choice was due to the greater energy efficiency of a project which was considered of national interest. The fact that the Hydroelectric Complex is present in the IIRSACOSIPLAN project portfolio and, therefore, is associated with an integration process, was not explained to the mayor; however, he was aware that it was a binational project. 
The hydroelectric plant would only benefit the municipality if its implementation considered and respected the interests of the population that would be affected, and especially, as the mayor emphasizes, if the damage compensations were fair. There is a promise, along with the coming plant, of local development, with greater economic dynamics and more employment opportunities in the region. But the latter is not among the urgencies of the municipality, since the population is employed almost in its totality. The coming of the project will be beneficial for the municipality, in the mayor's point of view, if there is a planning focused on the socioeconomic issues, in which development opportunities can be generated.

For the former mayor of the municipality of Garruchos, the project is seen as a promoter of major changes in the municipality, with several impacts. What could not yet be said is whether these impacts will be positive or negative for the residents. He pointed out that at no time the municipality's point of view was consulted about receiving the hydroelectric plant, and thus, no specific compensation was required. Again, it makes evident the lack of protagonism of the local administrators concerning the implementation of the Hydroelectric Complex.

In addition to the infrastructure works, the paved road connection between Garruchos and the reconstruction of the affected areas, another benefit of the construction of the hydroelectric plant is the increase in the tax collection the municipality will have based on the use of the water from the Uruguay River. The mayor did not know that IIRSA-COSIPLAN was one of the promoters of the construction of the Garabi-Panambi Hydroelectric Complex, or that it had an international or binational character. This fact shows the distance between binational and municipal interests and the lack of communication among the entities involved.

\section{FINAL CONSIDERATIONS}

There is some difficulty and uncertainty about the future of studies that address regional integration. This is due to the fact that these initiatives are linked to a political will, which, in South American countries, may change in four or five years, due to government party changes. Thus, issues related to integration are not considered by a state program, where the national interest prevails, but only by those who are temporarily in power. However, these studies are considered to 
have great importance, since they reveal the intentions of the countries concerning integration, as well as their intentions for the territory. What is perceived, over the years and with the maturity of some integrationist processes, is that none of them effectively made it possible for the South American countries to change their roles in the international scenario, which continue to be agribusiness exporters, an inheritance of the colonial process. As for the importance in the geopolitical scenario, we noticed that it occurs in an individual and punctual way. USAN, in itself, does not have great importance in the international scenario as the European Union, for example. Those who take this place, in the mentioned context, are the countries with the greatest economic importance in the subcontinent, depending on the subject that is discussed.

As for the physical integration, the Garabi-Panambi Hydroelectric Complex project could contribute to the process of transbordering at the border between Argentina and Brazil. The hydroelectric dams, when they are built at the border, promote the shared use of a resource and, therefore, this greater interdependence, intensifying the process of integration in a real way, in a lived way. This approach is already beginning with the construction of the Hydroelectric Complex (with labor coming from the two countries) and involves its operation, with the participation of equally shared technical workforce. These exchanges provide greater communication, from the physical and informational points of view, among people, municipalities and localities, helping the process of transbordering.

The negative impacts of this implementation weigh on those who live around the rivers that will receive the hydroelectric dams and who usually depend on them for their subsistence. Most of them are small farmers who use the rivers for irrigation and fishing. The indigenous people are also very vulnerable, as they may be located along the banks of the rivers or in the reservations for the preservation of their culture and habits. In addition to the repercussions that are considered concrete, such as the loss of their lands and houses, the flood in riparian forests, there are also immaterial repercussions, such as the feeling of topophilia, the loss of neighborhood relationships that lasted for decades, the impossibility of returning to certain places because they no longer exist, the flooding of places considered sacred by the indigenous culture, the establishment of a new contact with the river.

According to the local actors, it is estimated that, with the increase in the circulation of people in the host municipalities (Alecrim and Garruchos), demands 
for public facilities should increase. The construction of schools, health centers and housing will become essential, albeit provisionally. Within this new set of demands, older demands of the municipalities (that were not met because they did not have the necessary visibility) may be present and take advantage of the moment.

It is noticed that the territory is still in dispute. The national and international interest takes precedence over the will and the wishes of the local residents. The conflict is also present locally among local territorial actors, through distinct views of MAB and mayors on the construction of the Garabi-Panambi Hydroelectric Complex. These different views, besides that of the federal governments, create in that space a dispute of intentionalities, in which the federal governments, organized by USAN, use their Power to impose a new use of this territory, disrespecting the citizens' relation with their space and with the traditional forms of use.

It is understood that the implementation of Garabi-Panambi fulfills clear objectives, which involve energy integration and support to the growth that the South American countries, mainly Brazil, have had, even though that was slowed by the world economic crisis of 2008. With the intention of building these hydroelectric plants, the National States' will to maintain the same development goals as those promoted in the 1970s is reaffirmed. Even if the Garabi-Panambi Hydroelectric Complex complies with these Argentine and Brazilian energy needs, it must be considered that local territorial actors must have broad participation in the project, not being on the sidelines, as they currently are. It is worth remembering that this lack of participation by civil society and government representatives has already been detected (SENHORAS, 2008). This is due, according to Mariano (2014), to the institutional organization of the institution that promotes integration. Thus, even if measures have been taken over time by IIRSA-COSIPLAN, the Federal Government and the state of Rio Grande do Sul, mechanisms to address this need are still urgent.

The integrative nature of the infrastructure promoted by IIRSA-COSIPLAN seemed to be, in the analysis made from the local actors' view, something of little importance, which was left aside; few people link the project to COSIPLAN or IIRSA. Thus, once again, IIRSA-COSIPLAN resembles a set of projects that fulfill national interests, and which sometimes manage to contribute to South American integration. Even though Garabi-Panambi are now linked to an integration process, they were not originally designed in this perspective, as they were rather 
part of a binational agreement between Argentina and Brazil. Therefore, it is the national interests that pervade this megaproject, leaving aside what is claimed by USAN concerning the integration of peoples and the respect for cultures. As for its implementation, the Hydroelectric Complex keeps the same distance with the local communities (and their wishes, doubts and future perspectives). As for the impacts, what can make them more lenient, if this is possible, is precisely a real rapprochement, creating a space for effective dialogue with the population.

IIRSA-COSIPLAN, through Garabi-Panambi, can modify the historical missionary territory. The first transformation occurs with the reaffirmation of old projects that are still considered in its portfolio, supporting the affirmation that IIRSA-COSIPLAN does not break the model within which the subcontinent was thought in the past. The other changes are present in the alteration of territory use, in the destruction of archaeological sites from the time of Jesuit Reductions, and alter the relation of the population with the river (feeling of belonging), as well as the intensification of the flows in the subcontinent.

The missionary territory, which in the past was used for the indigenous way of life and subsistence, and was the meeting point of Western and local cultures when the territory was produced, today is used to fuel a capitalist society, which sees in its demand for energy consumption reason enough to change the uses of places that not even have access to basic infrastructure. Different times and functions have accumulated in this territory where integrationist projects and their physical and energetic articulations are confronted with the reality of marginalization of the Guarani indigenous peoples. The tradition, culture and way of life of these traditional peoples are revealed even in the territory toponyms, but their fates seem to find no space in the geopolitical analyses of integrationist processes. 


\section{REFERENCES}

Brasil. (2014). Ministério do Turismo. Anuário Estatístico de Turismo.

Centrais Elétricas Brasileiras S. A. (ELETROBRAS). (2010). Estudo de Inventário do Rio Uruguai no Trecho Compartilhado entre Argentina e Brasil. Novembro.

Corrêa, R. L. (1998). Territorialidade e Corporação: um exemplo. In Território: Globalização e Fragmentação. 4." ed. Editora Hucitec: São Paulo.

Costa, W. M. (1997). O Estado e as Políticas Territoriais no Brasil. 6. ed. São Paulo: Contexto.

Dietz, C. I. (2008). Cenários Contemporâneos da Fronteira Brasil-Argentina: infraestruturas estratégicas e o papel dos atores no processo de cooperação/integração transfronteiriça. Porto Alegre: UFRGS.

Entidad Binacional Yacyretá (EBY).(2009). Desarrollo Social en ambas Márgenes: El Plan de Acción para Reasentamiento y Rehabilitación (PARR).

Haesbert, R. (2003). Da Desterritorialização à Multiterritorialidade. Boletim Gaúcho de Geografia, 29, 11-24.

Hirt, C. (2013). O Papel do BNDES nas Políticas de Desenvolvimento e Integraçáo Regional. Revista Brasileira de Geografia e Econômica, 3.

Hurrell, A. (1993). Os blocos regionais nas Américas. Revista Brasileira de Ciências Sociais, 8, 98-118.

Instituto Brasileiro de Greografia e Estatística (IBGE). (2016). IBGE Cidades.

Instituto Nacional de Estadística y Censos (INDEC). (2014). Turismo Internacional.

Iniciativa para a Integraçáo da Infraestrutura Regional Sul-Americana (IIIRSA). (2012)

Conselho Sul-Americano de Infraestrutura e Planejamento (COSIPLAN).

IIRSA-COSIPLAN. (2017a). Ficha de Proyecto de la Construcción de Planta Hidroeléctrica de Garabi. Retrevied from http://iirsa.org/proyectos/detalle_proyecto.aspx?h=313

IIIRSA-COSIIPLAN. (2017b). Ficha de Proyecto de la Construcción de Planta Hidroeléctrica de Panambi. Retrevied from http://iirsa.org/proyectos/detalle_proyecto.aspx?h=1327

Itaipu Binacional. (2014). O que representa a energia da Itaipu para o Brasil e o Paraguai? Itaipu Binacional.

Levinton, N. and Snihur, E. (2011). El Porvenir de Misiones. Buenos Aires: Contratiempo Ediciones.

Mariano, M. (2014). O Papel do Brasil na Integração da Infraestrutura da América do Sul: Limites Institucionais e Possibilidades de Mudança. In NETO, Walter (org.). O Brasil e Novas Dimensôes da Integração Regional. Rio de Janeiro: IPEA, p. 230-290.

Nogueira, C. R. D. (2007). O Turismo, o Reencontro e a Redescoberta da Região das Missóes. São Paulo: USP. 
Padula, R. (2014). Da Iirsa ao Cosiplan da UNASUL: a Integração de Infraestrutura na América do Sul nos anos 2000 e suas Perspectivas de Mudança. In: O Brasil e Novas Dimensóes da Integração Regional. Rio de Janeiro: IPEA, p. 291-352.

Rsoseira, A. C. (2011). Nova Ordem Sul-Americana: Reorganização Geopolítica do Espaço Mundial e Projeção Internacional do Brasil. São Paulo: USP.

Rosière, S. (2007). Les acteurs géopolitiques. Géographie politique \& Géopolitique. 2 é édition. Paris: Ellipses Édition.

Santos, C. R. and Rüickert, A. A. (2014). Turismo, Fronteira e Território: Uma Análise do Território Transfronteiriço Missioneiro.In Anais do I Congresso Brasileiro de Geografia Política: Geopolítica e Gestão do Território, 2014. Rio de Janeiro, p. 1105-1016.

Santos, M. (2009). A Natureza do Espaço: Técnica e Tempo, Razão e Emoção. 4. ed. São Paulo: Edusp.

Santos, M. (2011). Por uma Outra Globalização: do pensamento único à consciência universal. Rio de Janeiro: BestBolso,

Santos, M. and Silveirra, M. L. O. (2001). Brasil. Território e sociedade no início do séc. XXI. Rio de Janeiro: Record.

Schallenberger, E. (2007). Estudos missioneiros: Temas e abordagens. In: São Francisco Xavier: nos 500 anos do nascimento de São Francisco Xavier: da Europa para o mundo 1506-2006. Porto: Centro Interuniversitário de História da Espiritualidade, p. 27-56.

Secretaria Nacional de Turismo (SENATUR). (2014). Turistas a Paraguay por Nacionalidad.

Senhoras, E. M. (2008). Regionalismo transnacional e integração física: um estudo sobre a iniciativa de integração da infraestrutura sul-americana. Campinas: Unicamp.

Unión de Naciones Sudamericanas (UNASUR). (2014). Cartera de Proyectos 2014. Retrevied from: <http://www.iirsa.org>.

Unión de Naciones Sudamericanas (UNASUR). (2017). União das Naçóes Sul-americanas. Cartera de Proyectos. Retrevied from http://www.iirsa.org

Vitte, C. C. (2006) Integração, soberania e território na América do Sul: um estudo da IIRSA. Revista Terra Livre, 2(27). 